\title{
Effect of Biodiesel Candlenut Seed (Aleurites Moluccana) to NOx Emission and Combustion Process on Single Cylinder Diesel Engine
}

\author{
Beny Cahyono ${ }^{1}$, Aguk Zuhdi Muhammad Fathallah², Vianto Ilham Pujinaufal ${ }^{3}$
}

\begin{abstract}
- fossil fuels are non-renewable fuels but are still the main fuel choice, however, it is now becoming increasingly recognized that the availability of fossil fuels are dwindling which further encourages research on renewable fuels. One of the renewable fuels under development and research is biodiesel. The use of vegetable and animal oil is one of the primary choices to decrease the use of non-renewable fuels. Candlenut oil is one of the alternatives under research and development to produce biodiesel as a replacement for non-renewable fuels. In this research is expected to know the NOx emission level and combustion process of single cylinder diesel engine using candlenut oil biodiesel and compared with diesel fuel HighSpeed Diesel (HSD). The results of NOx emission comparison between biodiesel candlenut and HSD showed an increase of $0.76 \mathrm{gr} / \mathrm{kWh}$ for biodiesel candlenut and $0.51 \mathrm{gr} / \mathrm{kWh}$ for HSD fuel. In the burning process test results showed the knocking value of better candlenut biodiesel than HSD which is 5.69 bar for biodiesel candlenut and 6.19 bar for HSD fuel.
\end{abstract}

Keywords—biodiesel, candlenut oil, combustion, diesel engine, emission, NOx.

\section{INTRODUCTION}

$\mathrm{T}_{\mathrm{b}}$ he number of motor vehicles in Indonesia continues to grow annually until 2016 totaling 129.2 million motor vehicles consisting of 105.2 million motorcycles, 14.5 million passenger cars, 7 million freight cars and 2.5 million cars bus [1]. Along with its growing use of motor vehicles then increased fuel consumption is also used. The availability of fossil fuels is currently depleted one of them because of the high usage of fuel oil (BBM) for transportation. On the other hand, fuel is one element that drives the transportation industry and other industries [2]. The way to prevent the depletion of fossil fuels is by finding renewable energy sources that not only less emission but also renewable. Renewable energy with promising prospect is biodiesel. Biodiesel can be used on almost every diesel engines, with or without any modification depends on the type of biodiesel [3]. Biodiesel is a fuel made with chemical processes from oils produced by plants or from animal fats and alcohol content that can be used on diesel engines, with or without diesel petroleum blends. Some of the raw materials that can be used as biodiesel are palm oil, soybean, jatropha curcas, sugarcane, and some other plant species.

The objective of this research is discussed the emissions issued by diesel engines from the remaining result of combustion of biodiesel by using raw materials of candlenut. This research is using experimental

Beny Cahyono, Department of Marine Engineering, Institut Teknologi Sepuluh Nopember, Surabaya, 60111, Indonesia. E-mail: benyjtsp98@gmail.com

Aguk Zuhdi Muhammad Fathallah Department of Marine Engineering, Institut Teknologi Sepuluh Nopember, Surabaya, 60111, Indonesia. E-mail: fathalaz@its.ac.id

Vianto Ilham Pujinaufal, Department of Marine Engineering, Institut Teknologi Sepuluh Nopember, Surabaya, 60111, Indonesia. E-mail: viantoilham@gmail.com method. The results of biodiesel emission test data made from standard candlenut seeds will be compared with HSD fuel. One of the raw materials that can be utilized to be biodiesel is candlenut. Based on the results of the research [4] biodiesel from candlenut oil was obtained by esterification process to decrease free fatty acid (FFA) content from $7 \%$ to $0.8 \%$. The next process is transesterification to separate between glycerol and biodiesel of candlenut oil by using $\mathrm{KOH}$ as a catalystt. [4], explains that the process of making candlenut biodiesel through a fairly simple process. The first process is esterification process to decrease free fatty acids (FFA) level from $7 \mathrm{wt} \%$ to $0.8 \mathrm{wt} \%$ by using methanol and $\mathrm{H}_{2} \mathrm{SO}_{4}$ mixture as a catalyst which then heated at $65^{\circ} \mathrm{C}$. In the second process the transesterification process is done by using a mixture of vinegar and also $\mathrm{KOH}$ as much as $1 \mathrm{wt} \%$ which then heated at $40^{\circ} \mathrm{C}$ for about 60 minutes or until visible glycerol. In this research the limitation of NOx emission levels refers to IMO regulations. The Tier III control applies only to ships specified during operation in the Emission Control Area (ECA) defined to limit NOx emissions, beyond which Tier II control areas are applicable. In accordance with Rule 13.5.2, certain small ships will not be required to install a Tier III engine. Marine diesel engines installed on boats built on or after January 1, 2016 and operating in the ECA of North America and ECA of the Caribbean Sea of the United States must comply with NOx Tier III standards (IMO) [5][6][7][8]. Conducted experiments in comparison of diesel engine combustion process from biodiesel fuel oil of amarphullus onchophillus and pertamina dex by using YANMAR TF85-MH machine and got conclusion that amarphullus onchophillus biodiesel produce more heat, ignition delay is longer and produce the highest maximum pressure when compared with pertamina dex. Compared to conventional diesel fuels, oxygencontaining fuels in biodiesel can increase combustion more and thereby reduce particles (PM), carbon monoxide (CO) and total hydrocarbons (THC) in 
compression ignition engines, while increasing $\mathrm{NOx}$ nitrogen oxides). [9][10][11][12]

\section{METHOD}

The method used in this research is experimental method. Before the experiments start, first of all the diesel engine have to be prepared the preparation to be performed before the test on the YANMAR TF-85 engine is done in advance of the engine set up, the test is conducted on a single-cylinder YANMAR TF-85 engine with a capacity of $493 \mathrm{cc}$ using bio-diesel fuel B20 candlenut and HSD fuel as material burn comparison. Some things that must be prepared in the process of testing combustion process other than diesel engine is pressure tranducer, crank angle encoder, computer and load. To capture NOx emission data some components to be prepared are encoder, gas analyzer loader and computer. Here is the design of the engine set up for data retrieval process combustion and test NOx oil biodiesel oil candlenut in figure 1 and 2.

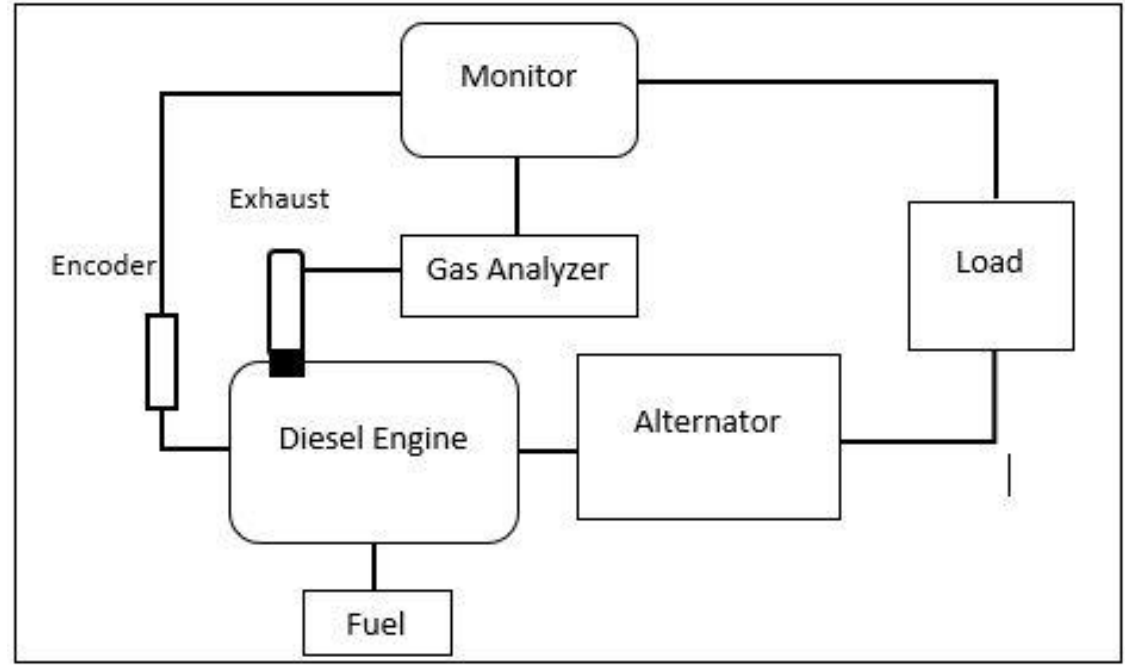

Figure. 1. Engine Set Up for Emission Test

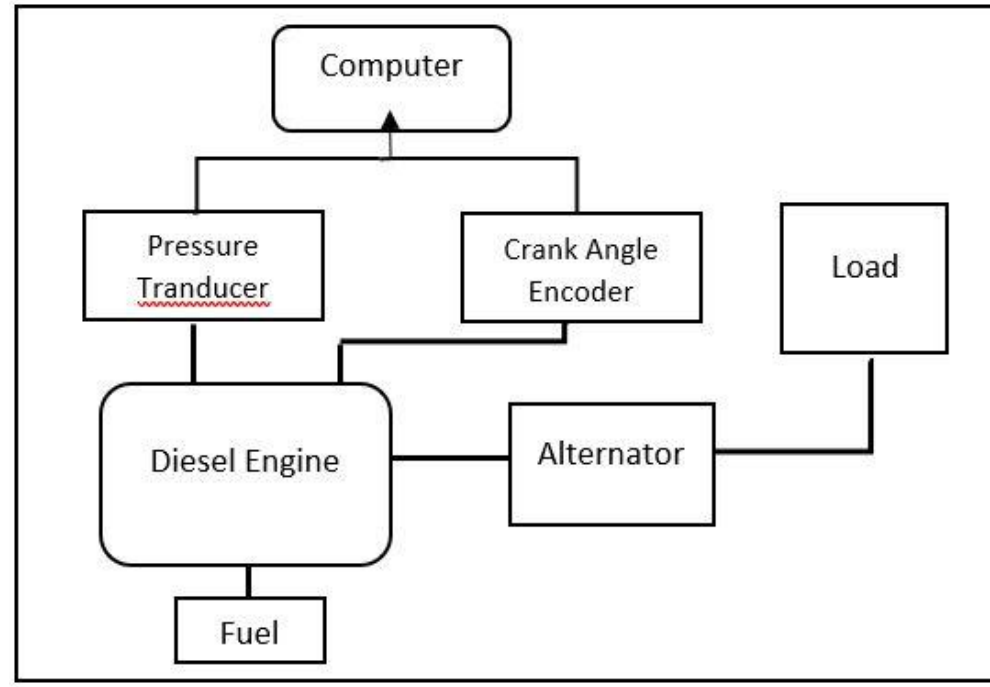

Figure. 2. Engine Set Up for Combustion Test

The experiments carried out in this research were combustion process and emission levels produced by diesel engines with oil. There are three main stages in the making of biodiesel made from the seeds of candlenut, namely:

1. Initial stage;

2. The main reaction stage;

3. Purification stage.

\section{A. Esterification}

Esterification aims to reduce the levels of Free fatty acids (FFAs) in candlenut oil. The content of FFA on candlenut oil is $(7 \mathrm{wt} \%)$. Esterification was done by mixing methanol by $8 \%$ and also using $\mathrm{H}_{2} \mathrm{SO}_{4}$ as much as $0.1 \%$ as a catalyst. Here are the steps performed in the esterification process of candlenut oil:

1) The seed oil of candlenut is heated and kept at a temperature of $35^{\circ} \mathrm{C}$.

2) Enter the methanol as much as $8 \%$ and stir for 5 minutes.

3) Enter $1 \mathrm{ml}$ of $\mathrm{H}_{2} \mathrm{SO}_{4}$ on every 1 liter of candlenut oil.

4) Stir for 60 minutes with temperature maintained at $35^{\circ} \mathrm{C}$.

5) Allow esterified oil for 8 hours. 


\section{B. Transesterification}

Transesterification is the second stage process to separate the glycerol content in the candlenut oil. Transesterification is done by mixing methanol as much as $12 \%$ and also $\mathrm{KOH}$ as much as $1 \%$ of the weight of candlenut oil. Here are the steps performed during the transesterification process:

1) Mix $12 \%$ methanol with $1 \% \mathrm{KOH}$ from the weight of candlenut seed oil and stir until methanol and $\mathrm{KOH}$ mixed.

2) Enter $50 \%$ of the methoxide mixture into the esterified candlenut oil and stir until temperature 57 ${ }^{\circ} \mathrm{C}$.

3) After the candlenut oil reaches $57^{\circ} \mathrm{C}$ temperature enter $50 \%$ mixture of metoxide and stir for $60-90$ minutes at $57^{\circ} \mathrm{C}$ until visible glycerol which begins to separate with the oil of candle nut.

4) Wait for 2-3 hours until the glycerol settles below and completely separate from the oil of candlenut.

\section{Washing}

The washing process is the FAME purification process resulting from transesterification. The process of purification or washing using vinegar as much as $7 \mathrm{ml}$ per 1 liter and aquadest with a ratio of 1: 1 with FAME transesterifikasi results. The washing process is repeated 2-3 times until the glycerol solution is completely separated from the FAME liquid indicated by the clearest aquadest solution and the $\mathrm{pH}$ shows the number 7 .

\section{Destilation}

The destilation process is the drying process of the remaining water content or aquadest present in FAME. The drying process is carried out by heating FAME until the water content or aquadest evaporates at $85^{\circ} \mathrm{C}$ for approximately 30-60 minutes. In the final process biodiesel will change color to bright yellow. In addition to making biodiesel, the important thing is about the characteristics of candlenut oil biodiesel. There are 5 parameters tested for candlenut oil biodiesel, here are 5 characteristic parameters of candlenut oil biodiesel:

\section{1) Density}

Density is the specific gravity of the oil that is affected by the temperature, the lower the temperature value the higher the density value and the opposite. The specific gravity of this candlenut oil biodiesel is $938.7 \mathrm{~kg} / \mathrm{m} 3$.

2) Viscocity

The size of the viscosity of this fuel will be very important because the value of this viscosity will be very influential when the injector inject fuel into the combustion chamber, the higher the viscosity value the spraying of fuel will be more imperfect and vice versa, the lower the viscosity value will be more perfect spraying. The national standard for viscosity values is 2,3 - 6 Cst and the viscosity value of the candlenut biodiesel fuel is 4.6 - 6 Cst. This means that the viscosity value of candlenut oil biodiesel meets the national standard of biodiesel quality.

3) Flash Point

Flash point is a value that shows at what temperature the fog of fuel will start burning. At national standard indicated that minimum flash point temperature is 100 $\mathrm{oC}$ and flash point value from biodiesel kemiri oil is 225 oC. it shows that the fuel biodiesel of candlenut oil meet the standard flash point value refer to Indonesian National Standard (SNI).

4) Pour Point

Pour point is the value or temperature limits in which the fuel begins to form paraffin crystals which, when formed will clog the flow of fuel into the combustion chamber. The pour point value of the candlenut oil biodiesel is $180 \mathrm{C}$ and the maximum pour point according to Indonesian National Standard (SNI) is 18oC. it shows that pour point value of candlenut oil biodiesel meet Indonesian National Standard (SNI).

5) Calorific Value

The calorific value is the amount of heat value or which can be generated by a fuel in the combustion process. The calorific value of the biodiesel oil of candlenut oil is 9.387 Cal/gr.

TABLE 1.

PROPERTIES OF B20 CANDLENUT

\begin{tabular}{llccc}
\hline \multicolumn{1}{c}{ Parameter } & \multicolumn{1}{c}{ Unit } & B20 Candlenut & $\begin{array}{c}\text { Result of Tests } \\
\text { B20 Candlenut (Pham, 2018) }\end{array}$ \\
\hline Density at $15^{\circ} \mathrm{C}$ & $\mathrm{kg} / \mathrm{m}^{3}$ & 916 & 887 & Test Method \\
Viscosity at $40^{\circ} \mathrm{C}$ & $\mathrm{Cst}$ & $4,6-6$ & 4,24 & ASTMD 1480 -81 \\
Flash Point & ${ }^{\circ} \mathrm{C}$ & 225 & 6,3 & ASTMD 93 - 00 \\
PourPoint & ${ }^{\circ} \mathrm{C}$ & -18 & ASTMD 97 -85 & Bomb Kalorimeter \\
Calorific Value & $\mathrm{Cal} / \mathrm{gr}$ & 9,387 & & \\
\hline
\end{tabular}

\section{RESULTS AND DISCUSSION}

\section{A. Maximum Pressure Result of Candlenut Biodiesel} (B20) and HSD Fuel

Figure 7 shows the comparison graph of the maximum pressure value. Maximum pressure analysis is performed to determine the maximum pressure value of fuel during combustion process and also its position when reaching the maximum pressure. At RPM 2200 and the $1 \mathrm{~kW}$ power load generated by the B20 candlenut fuel is 1.181 $\mathrm{kW}$ and the power generated by HSD fuel at RPM and the same load is $1.107 \mathrm{~kW}$. Figure 7 shows a graph showing that the maximum pressure of the B20 candlenut fuel is 61.44 bar at position $5^{\circ}$ which means slightly smaller when compared to the maximum pressure of HSD which is worth 61.69 bar at position $5^{\circ}$. 


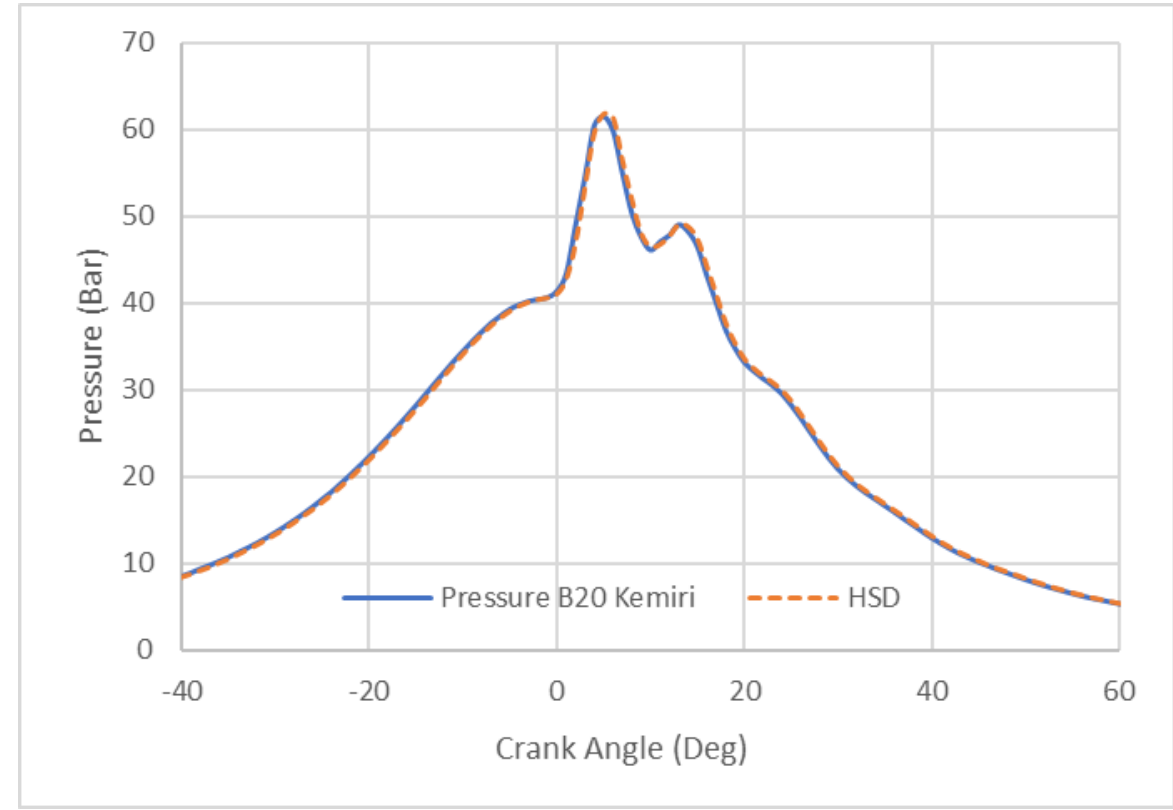

Figure. 3. Graph of Maximum Pressure

B. Rate of Heat Release Result of Candlenut Biodiesel (B20) and HSD Fuel

The analysis of the rate of heat release is done by comparing the beginning of the rate of heat release and comparing the peak of rate of heat release of each fuel. At RPM 2200 and the load of $25 \%$ power from by fuel B20 candlenut is $1.181 \mathrm{~kW}$ and power generated by HSD fuel at RPM and the same load is $1,107 \mathrm{~kW}$. In figure 7 we can see the graph showing the ratio of heat release rate between B20 candlenut fuel and HSD fuel. In graph it can be seen that the start of energy release process B20 candlenut that is at 20 after TDC and its rate of heat release is 3,623 kJ / m3 / deg. In graph 4 it can also be seen that the process of initiation of energy release on HSD fuel also starts at 20 after TDC and its rate of heat release is also $3,623 \mathrm{~kJ} / \mathrm{m} 3 / \mathrm{deg}$, while for peak of rate of heat release of B20 candlenut is $68,561 \mathrm{~kJ} / \mathrm{m} 3 / \mathrm{deg}$ at 30 after TMA and the peak of rate of heat release value of HSD fuel is $72.268 \mathrm{~kJ} / \mathrm{m} 3 / \mathrm{deg}$ at $3 \mathrm{o}$ after TDC.

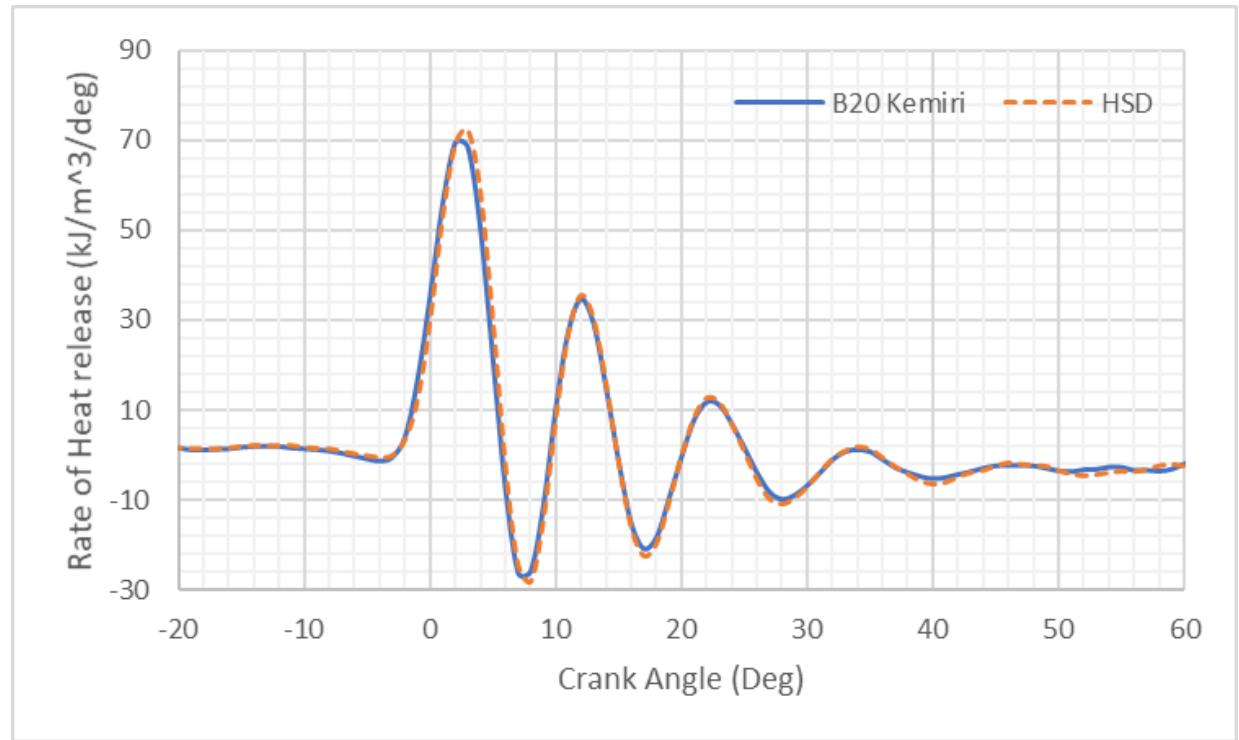

Figure. 4. Graph of Rate of Heat Release

C. Heat Release Result of Candlenut Biodiesel (B20) and HSD Fuel

The heat release analysis is done by comparing the highest peak heat energy point achieved by each fuel and its decrease of heat energy. In the picture can be seen graph showing the comparison of heat release between biodiesel seed candlenut and HSD fuel. In the graph it can be seen that the heat release value for HSD fuel at
RPM 2200 and the load of $1 \mathrm{~kW}$ is $499.37 \mathrm{~kJ} / \mathrm{m} 3$ at 24 oCA after TMA, whereas for B20 the peculiar value of heat release at RPM 2200 and the load of $25 \%$ is 499,71 $\mathrm{kJ} / \mathrm{m} 3 / \mathrm{deg}$ at 24 oCA after TDC. It shows that the highest energy value of B20 candlenut is smaller when compared to the highest energy value of HSD fuels while for the value at the time of decreasing of HSD and B20 
candlenut energy energy tends to be the same that is in lift $424 \mathrm{~kJ} / \mathrm{m} 3$ at the angle 89 oca after TDC.

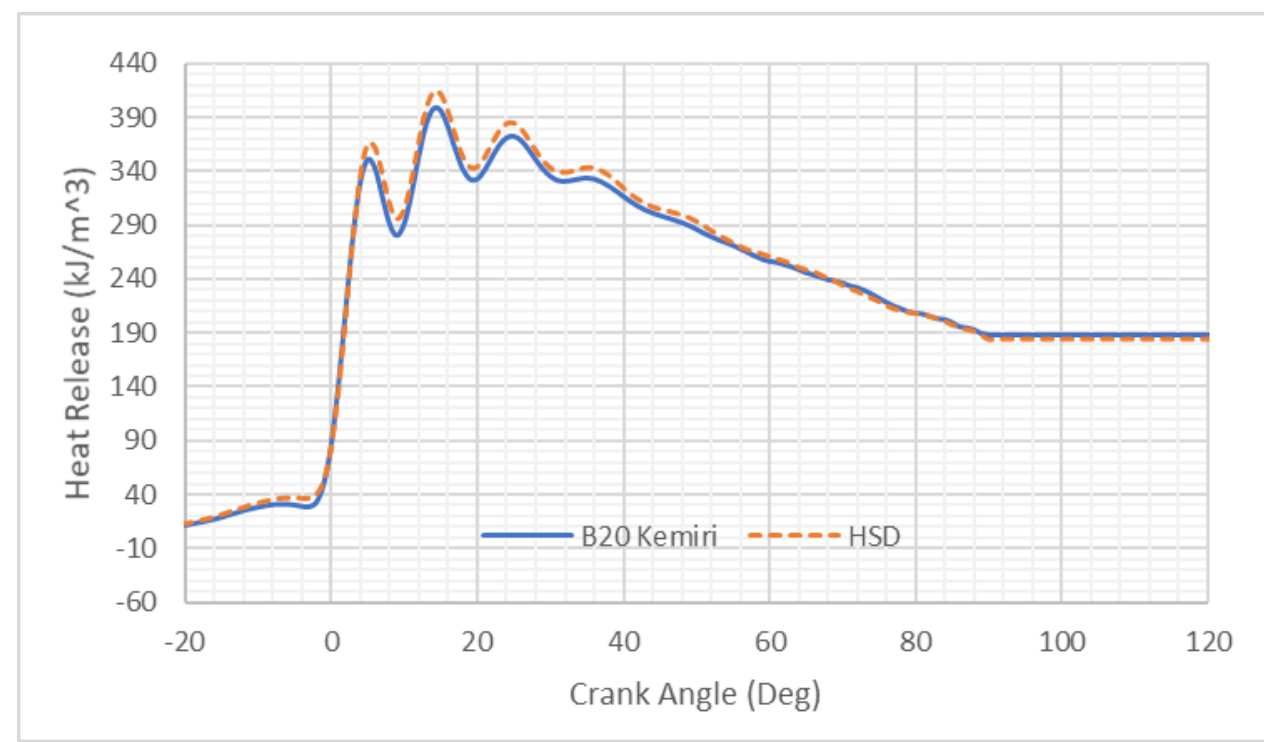

Figure. 5. Graph of Heat Release

D. Knock Detection Result of Candlenut Biodiesel (B20) and HSD Fuel

Knock detection analysis is done by reading the peak pressure generated by each fuel. Knock detection is caused by the occurrence of an explosion that is not timely, it could be after the injection process or before the injection process. At RPM 2200 and a $25 \%$ power load of B20 candlenut fuel is $1.181 \mathrm{~kW}$ and power generated by HSD fuel at RPM and the same load is $1.107 \mathrm{~kW}$. In Figure 4.12 can be seen graph showing the data knock detection of HSD fuel and also B20 candlenut. In Figure 4.12 it can be seen that the HSD fuel knock detection value at RPM 2200 and the load of $1 \mathrm{~kW}$ is 6,192 bar at the 5o angle position after TMA, whereas in the biodiesel fuel the hazard value of knock detection at RPM 2200 and the load of $1 \mathrm{~kW}$ is 5.69 bar at $4 \mathrm{o}$ angle after TMA. It can be deduced that HSD's fuel knock detection value is greater than that of the B20 hazard knock detection at RPM 2200 and the load of $25 \%$.

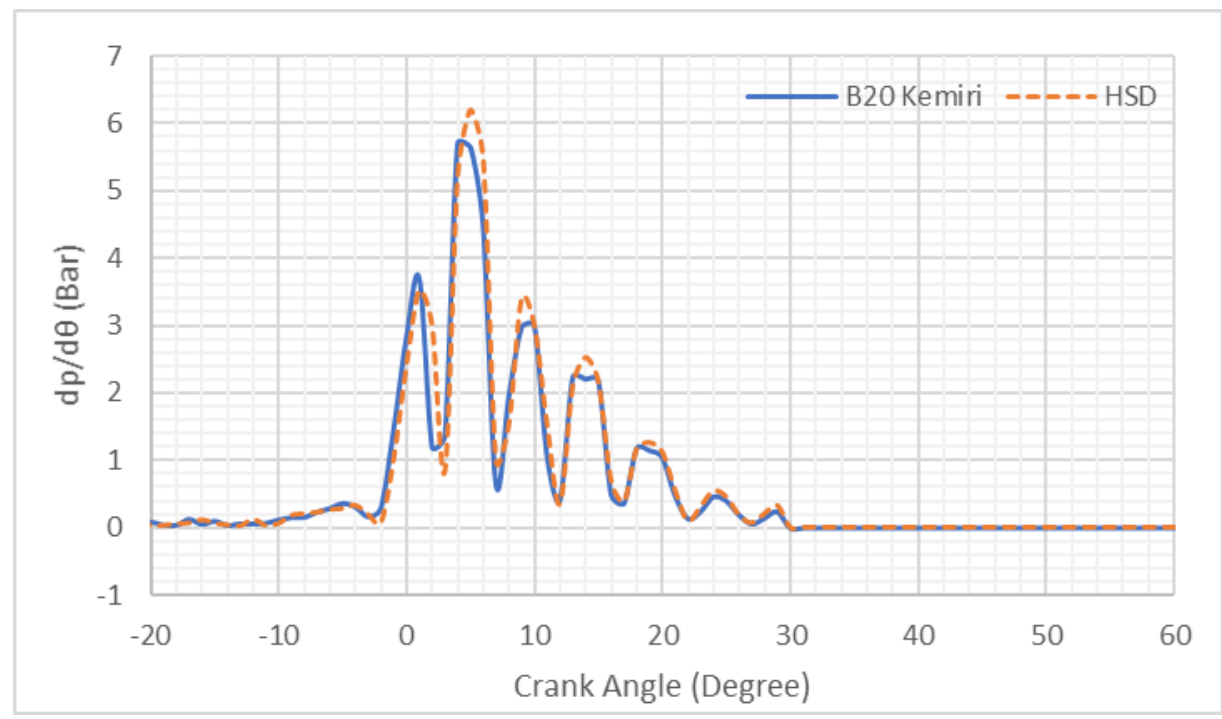

Figure. 6. Graph of Knock Detection

\section{E. Knock Detection at All Load}

Figure 4.19. above shows the value of knock detection at each load that is $25 \%, 50 \%, 75 \%, 100 \%$ load seen on the graph that the knocking value of HSD fuel is always on the fuel B20 candlenut and the trend shown is the greater the power then the knocking value is smaller except at $100 \%$ loading whose value tends to be the same between biodiesel fuel B20 candlenut and HSD fuel. 


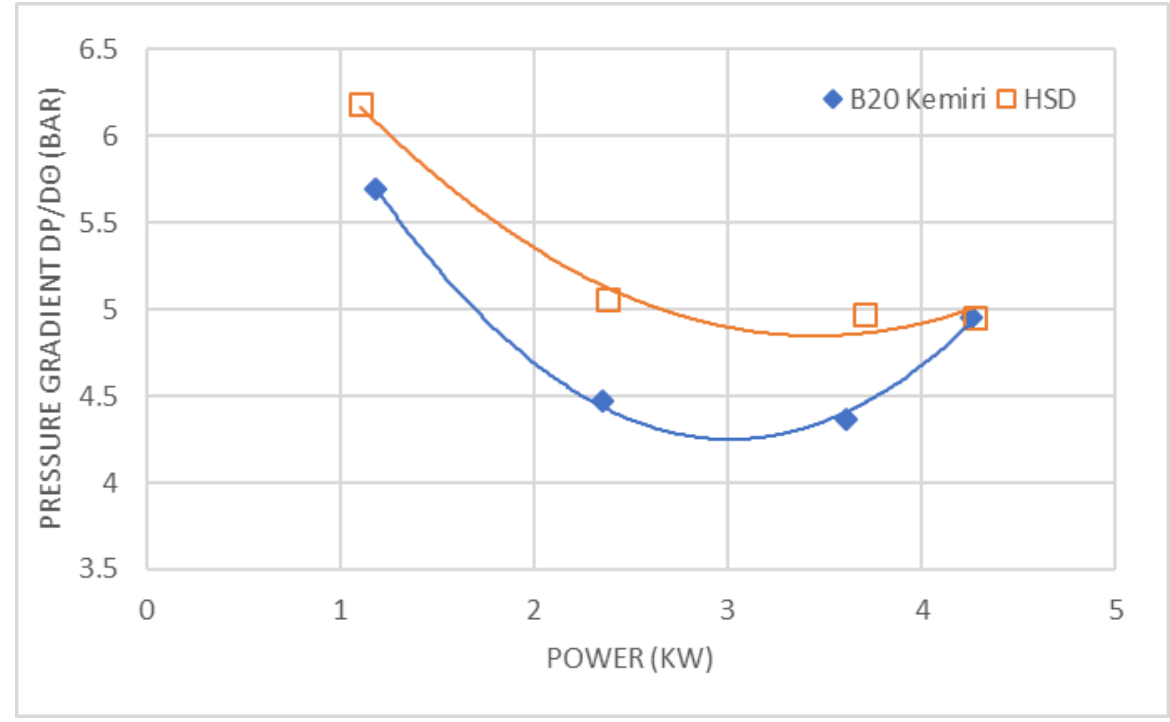

Figure.7. Graph of Knocking at All Load

\section{F. Ignition Delay Result of Candlenut Biodiesel (B20) and HSD Fuel}

Figure 6 shows a comparison graph of ignition delay values between B20 candlenut biodiesel and HSD fuel. The ignition delay analysis aims to determine the lag time that begins at the beginning of fuel injection by the injector until the fuel time burns in the combustion chamber. This experiment was conducted by varying the four loads with the maximum RPM. The YANMAR TF $85-\mathrm{MH}$ diesel engine has an injection time at 180 before the top dead point. From Figure 6 above it can be seen that the ignition delay time of B20 candlenut at $1 \mathrm{~kW}$ load is $1.20 \mathrm{~ms}$ and the ignition delay time of HSD is $1.20 \mathrm{~ms}$ also, for ignition delay time B20 candlenut at 2
$\mathrm{kW}$ load is $1,125 \mathrm{~ms}$ and ignition time delay for HSD fuel at $2 \mathrm{~kW}$ load is also worth $1.125 \mathrm{~ms}$, for ignition delay time of B20 candlenut fuel at $3 \mathrm{~kW}$ load is 1.05 while ignition delay time of HSD fuel is longer that is $1,2 \mathrm{~ms}$, and for time ignition delay the B20 candlenut fuel at $4 \mathrm{~kW}$ load is 1.05 and the HSD fuel has a longer ignition delay time of $1.125 \mathrm{~ms}$. The ignition delay time is influenced by the cetane number of the fuel. The higher the cetane number that is owned by a fuel the faster the fuel burns, which means the ignition delay time is smaller. Therefore, based on graphical ignition delay data in Figure 4.3 it can be assumed that the cetane number B20 candlenut is higher when compared to the HSD fuel cetane number.

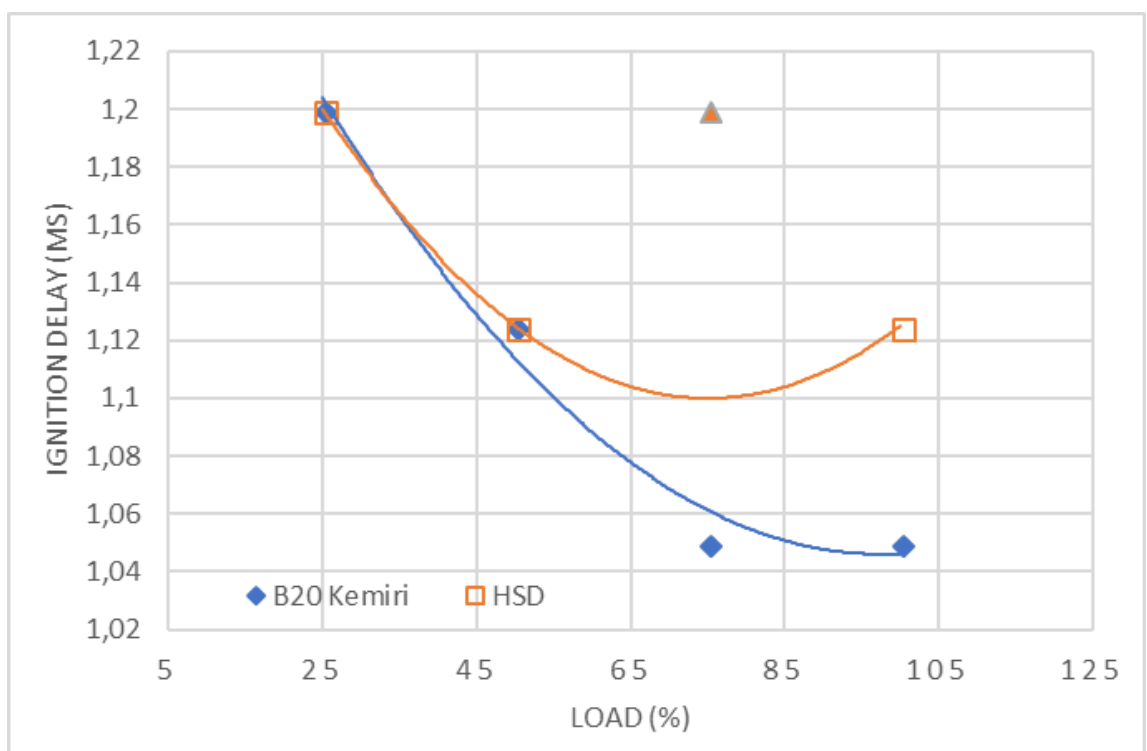

Figure. 8. Graph of Ignition Delay

G. NOx Emission Test Result of Candlenut Biodiesel (B20) and HSD Fuel

NOx emission analysis was performed to determine the ratio of $\mathrm{NOx}$ emission value between candlenut biodiesel (B20) and HSD fuel. The NOx emission analysis process begins with an emission test using a gas analyzer to get the PPM value of each B20 hazelnut fuel as well as HSD fuel. The experiments were conducted on a machine with a RPM 2200 and a load of $1 \mathrm{~kW}, 2$ $\mathrm{kW}, 3 \mathrm{~kW}, 4 \mathrm{~kW}$. Here is a graph showing the comparison of PPM values between B20 hazelnuts and HSD fuels: 


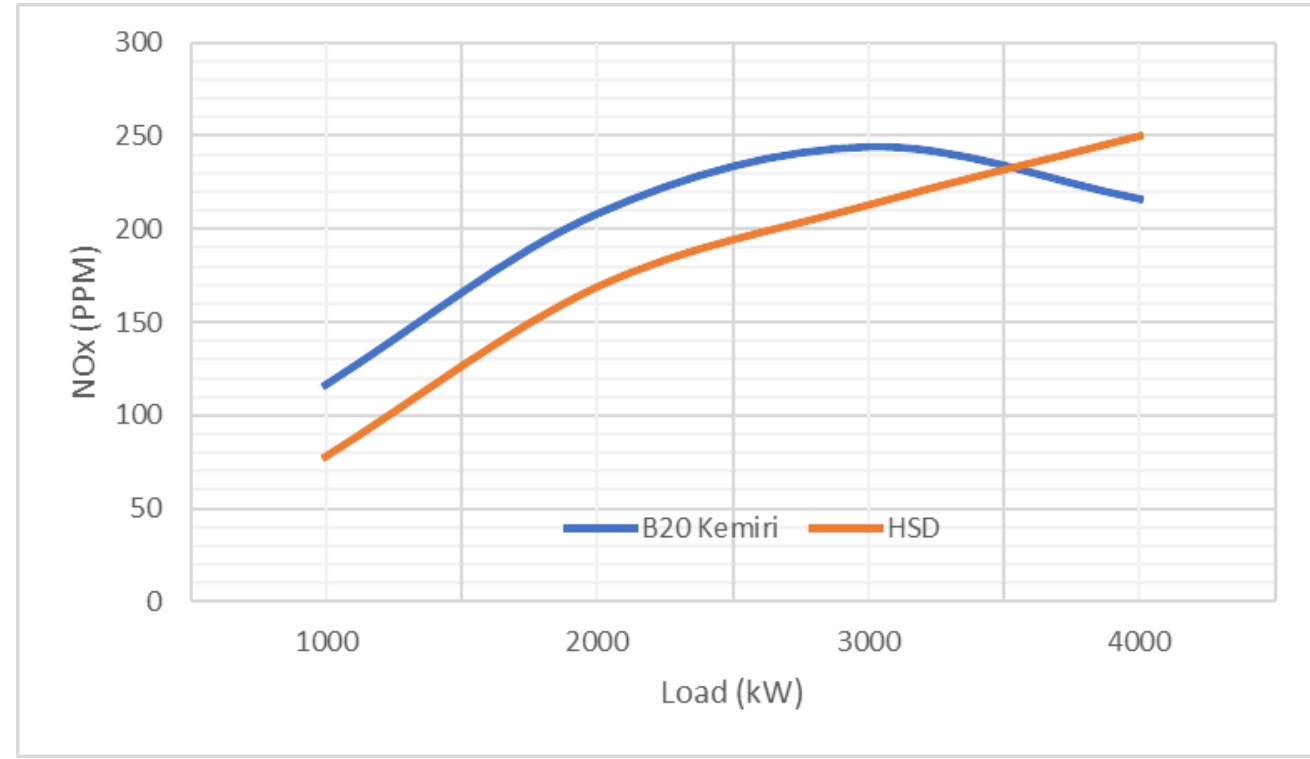

Figure. 9. Graph of NOx Emission (PPM)

Figure 4 shows the NOx emission content of B20 at a load of $1 \mathrm{~kW}$ and power of 1.181 is 116 PPM and the HSD NOx emission level at $1 \mathrm{~kW}$ load and power 1,107 is 78 PPM, it can be deduced that at $1 \mathrm{~kW}$ load NOx fuel emission of B20 candlenut is greater than that of HSD. At a load of $2 \mathrm{~kW}$ and 2.351 power of NOx fuel content of B20 hazelnut is 208 PPM and NOx HSD fuel emission levels at $2 \mathrm{~kW}$ load and 2,376 power is 169 , it can be deduced that at $2 \mathrm{~kW}$ load the B20 waxy fuel is greater compared to HSD fuel emission levels. At load 3
$\mathrm{kW}$ and power $3.611 \mathrm{NOx}$ fuel content of B20 hazard is 244 PPM and NOx emission level of HSD fuel at $3 \mathrm{~kW}$ load and 3,704 power is 213 PPM, it can be deduced that at $3 \mathrm{~kW}$ load of B20 candlenut fuel more large compared to HSD fuel emission levels. At a load of $4 \mathrm{~kW}$ and 4.256 powers of NOx fuel emission of B20 hazelnut is 216 PPM and HSD NOx emission content at $4 \mathrm{~kW}$ load and 4.276 power is $250 \mathrm{PPM}$, it can be deduced that at 4 $\mathrm{kW}$ load of HSD nuts more large compared to the B20 candlenut fuel level.

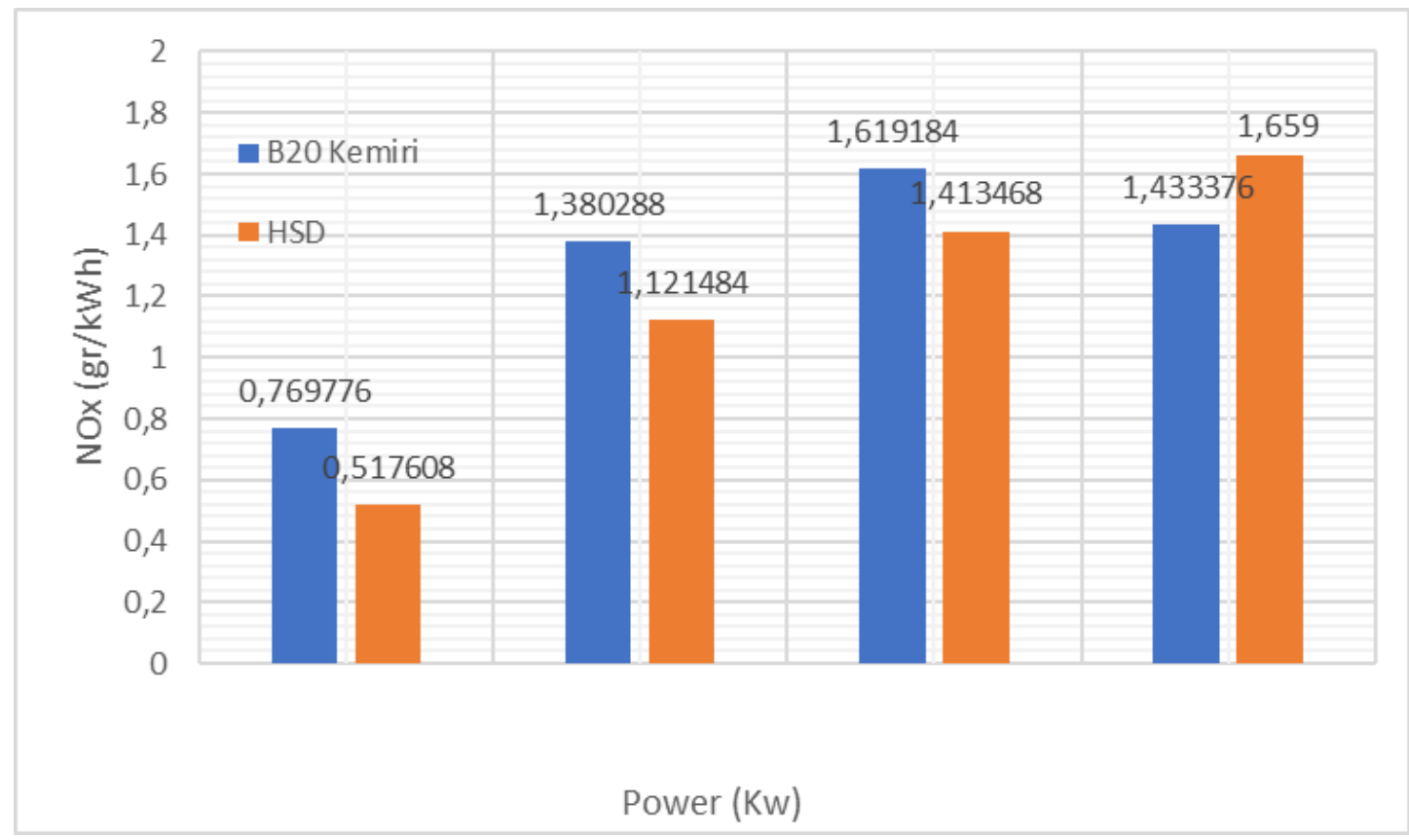

Figure. 10. Graph of NOx Emission (gr/kWh)

Figure 5 shows the NOx emission test result from the biodiesel of candlenut with B20 mixture compared with HSD fuel. Test method used in this test refers to IMO Marpol Annex VI that test is done at the maximum RPM (2200) on 4 different loads. Based on the graph attachment in figure 5 it can be seen that the NOx emission value generated by biodiesel is slightly lower than the NOx emission value generated by HSD fuel. In this research, the parameters used are 2200 RPM and at load $1 \mathrm{~kW}, 2 \mathrm{~kW}, 3 \mathrm{~kW}$, and $4 \mathrm{~kW}$. At $1 \mathrm{~kW}$ load and 2200 RPM B20 candlenut fuel has power of 1,181 kW and emission rate of NOx biodiesel of candlenut seed shows value of $0,769 \mathrm{gr} / \mathrm{kWh}$ this value larger than HSD emission rate with same load and RPM produce 1,107 
$\mathrm{kW}$ and NOx emission equal to $0,517 \mathrm{gr} / \mathrm{kWh}$. At a load of $2 \mathrm{~kW}$ and $2200 \mathrm{RPM}$ of B20 candlenut fuel has power $2,351 \mathrm{~kW}$ and emission value of NOx shows the value of $1,380 \mathrm{gr} / \mathrm{kWh}$ this value is also greater than the value of NOx HSD with $2 \mathrm{~kW}$ and $2200 \mathrm{RPM}$ emissions that generate power of $2,376 \mathrm{~kW}$ produce $1,121 \mathrm{gr} / \mathrm{kWh}$. At a load of $3 \mathrm{~kW}$ and 2200 RPM B20 candlenut fuel has $3,611 \mathrm{~kW}$ power and NOx biodiesel emission rate shows a value of 1,619 $\mathrm{gr} / \mathrm{kWh}$ while the NOx HSD emission

\section{CONCLUSION}

Based on the result of this research, the emission level and the combustion process of biodiesel kemiri fuels with the composition of B20 candlenut and High Speed Diesel diesel fuel (HSD), can be drawn the following conclusion;

1. For the emission 1 evels produced, biodiesel fuel B20 has higher NOx emission levels when compared to HSD fuels at 1,000 watts, 2,000 watts, and 3000 watt loads, while at 4,000 watt of biodiesel B20 candlenut produces lower emission of NOx.

2. Combustion Process

a. In the graph of ignition delay at constant RPM is $2200 \mathrm{RPM}$ and the loading is increasing, the trendline of ignition delay value of B20 candlenut fuel is shorter when compared to HSD fuel. It can show that the cetane number B20 candlenut is larger when compared to the HSD fuel cetane number.

b. At the maximum pressure graph at constant RPM of 2200 RPM and the increasing loading, the maximum pressure value will continue to increase except at 3000 watt load. For the position of maximum degree of pressure, the higher the load given the degree will be closer to the TDC.

c. In the graph rate of heat release at constant RPM of RPM 2200 and the increasing load, the value of peak of rate of heat release decreases with increasing load. For the value of heat ratio of the rate of heat releases of HSD fuel is dominantly higher when compared to bio fuel diesel B20 candlenut.

d. In the knock-detection graph at constant RPM of 2200 RPM and the loading continues to increase, the knocking value of the candlenut fuel is always smaller than the HSD fuel except for the load 4 where the knocking value tends to be the same. rate at the same load and RPM has $3,704 \mathrm{~kW}$ power shows a value of $1,413 \mathrm{gr} / \mathrm{kWh}$. At a maximum load of 4 $\mathrm{kW}$ and 2200 RPM B20 cabdlenut fuel has 4,256 kW power and its NOx emission is $1,433 \mathrm{gr} / \mathrm{kWh}$, the value is smaller compared to the HSD fuel absorber level with a load of $4 \mathrm{~kW}$ and $2200 \mathrm{RPM}$ which produces a load of 4,276 and issuing NOx emission rate of 1,659 gr/kWh.

\section{REFERENCES}

[1] Kementrian Pertanian Direktorat Jenderal Hortikultura. 2015. Statistik Produksi Hortikultura 2014.

[2] Budiyono, A. 2001. Pencemaran Udara: Dampak Pencemaran Udara Terhadap Lingkungan.

[3] Standar Nasional Indonesia, 2015, Regulasi Biodiesel, SNI 7182:2015, hal.1-3

[4] Pham, L. N, Dkk, 2018. Production of Biodiesel from Candlenut Oil Using a Two-step Co-solvent Method and Evaluation of Its Gaseous Emissions, Faculty of Chemistry, VNU University of Science, Hanoi, 19 Le Thanh Tong, Hoan Kiem District, Hanoi, Vietnam.

[5] Gusma, H, 2016., Analisis Perbandingan Combustion Process Mesin Diesel dari Bahan Bakar Biodiesel Minyak Umbi Porang (Amarphopallus Onchophillus) dengan Minyak Kelapa Sawit (Crude Palm Oil) Berbasis Eksperimen., Departemen Teknik Sistem Perkapalan., Fakultas Teknologi Kelautan, Institut Teknologi Sepuluh Nopember., Surabaya.

[6] Semin, Adhi Iswantoro, Gage Cendekiaji Hadi, "Biodiesel Cotton Seed Oil Performance Analysis on Diesel Engine", International Journal of Marine Engineering Innovation and Research, 2018, Vol. 2, No. 4, ISSN: 2548-1479, page 235241

[7] Dennis Y. C. dan X. Wu, 2010. A review on biodiesel production using catalyzed transesterification., Department of Mechanical Engineering., The University of Hong Kong., Pokfulam Road., Hong Kong, China.

[8] Syahrani,A., 2006, Analisa Kinerja Mesin Bensin Bedasarkan Hadil Uji Emisi,SMARTek., Teknik Mesin Fakultas Teknik Universitas Tadulako, Palu.

[9] Xing L, Dkk, 2003. Effect of Cetane Number Improver on Heat release Rate and Emissions of High Speed Diesel Engine Fueled with Ethanol-Diesel Blend Fuel., Institut of Internal Combustion Engine., Shanghai Jiaotong University., Shanghai.

[10] Semin, Adhi Iswantoro, Fatekhun Faris, "Performance and NOx Investigation on Diesel Engine using Cold EGR Spiral Tube: A Review", International Journal of Marine Engineering Innovation and Research, 2017, Vol. 1, No. 3, ISSN: 2548-1479

[11] Ardi, R. 2008. Pengujian Emisi Gas Buang pada Mesin Diesel yang Menggunakan Bahan Bakar Biodiesel dan Bahan Bakar Solar.

[12] Alhaq,S., 2016.,Analisa Emisi Berbasis Eksperimen dan Kelayakan Ekonomis Bahan Bakar Biodiesel Umbi Porang (Amarphallus Onchopillus) ., Departemen Teknik Sistem Perkapalan., Fakultas Teknologi Kelautan, Institut Teknologi Sepuluh Nopember., Surabaya. 